\title{
Identification of the Escherichia coli cys $M$ Gene Encoding $O$-Acetylserine Sulphydrylase B by Cloning with Mini-Mu-lac Containing a Plasmid Replicon
}

\author{
By AGNIESZKA F. SIRKO, MALGORZATA ZATYKA AND \\ M. DANUTA HULANICKA* \\ Institute of Biochemistry and Biophysics, Polish Academy of Sciences, Rakowiecka 36, \\ 02-532 Warsaw, Poland
}

(Received 10 November 1986; revised 11 February 1987)

\begin{abstract}
A region located at around 52' on the Escherichia coli chromosome was cloned by use of mini-Mulac containing a plasmid replicon and recloned into pBR322. Enzyme assays on transformants carrying the cloned fragments indicated the presence in the latter of the cys $A$ and $c y s M$ genes coding for sulphate permease and $O$-acetylserine sulphydrylase B, respectively.
\end{abstract}

\section{INTRODUCTION}

In Salmonella typhimurium the presence of two genes, $c y s K$ and $c y s M$, encoding $O$-acetylserine sulphydrylases A and B (OASS-A and OASS-B), respectively, is well documented (Hulanicka et $a l ., 1979)$. Either isoenzyme alone is sufficient for normal aerobic growth of bacteria on sulphate as sulphur source. The prototrophy of cys $K$ mutants of Escherichia coli suggests the existence of two isoenzymes in this organism also (Fimmel \& Loughlin, 1977; Wiater \& Hulanicka, 1979). However, there is no published report of the existence of the second sulphydrylase-encoding gene. Boronat et al. (1984) located a gene specifying $O$-acetylserine (thiol)-lyase on the $E$. coli genome by analysing peptide synthesis directed by plasmids carrying DNA fragments from around $52^{\prime}$ of the E. coli chromosome. Earlier, the gene order in this region had been established as: $52^{\prime}$ cys $A$ gsr ptsI ptsH cysK cysZ lig dsd 51' (Britton et al., 1982, 1983). A similar gene order for this region in $S$. typhimurium, namely cysK ptsHJ crr cysA, was established by Nelson et al. (1984).

In this paper we report the results of attempts to locate the second gene, cys $M$, encoding OASS, in this region of the $E$. coli chromosome by cloning the region with the aid of mini-Mu-lac containing a plasmid replicon.

\section{METHODS}

Bacterial strains, plasmids and phages. These are listed in Table 1. Phage Pl lysates were prepared and transduction was performed according to Miller (1972). All procedures for handling Mu bacteriophage were as described by Bukhari \& Ljungquist (1977).

Media and culture conditions. All Mucts lysogenic cells were grown at $30^{\circ} \mathrm{C}$ to avoid Mu repressor inactivation. Sulphur-free minimal medium (SF) was as described by Hulanicka et al. (1972) and $1 \mathrm{~mm}$-djenkolic acid or $1 \mathrm{mm-}$ sodium thiosulphate were used as sulphur sources. To check the triazole resistance of bacteria, 10 mM-1,2,4triazole was used in the media. L-Broth (Luria \& Burrows, 1957) was used routinely. Antibiotic supplements were ampicillin $\left(50 \mu \mathrm{g} \mathrm{ml}^{-1}\right)$, tetracycline $\left(25 \mu \mathrm{g} \mathrm{ml}^{-1}\right)$ or chloramphenicol $\left(30 \mu \mathrm{g} \mathrm{ml}^{-1}\right)$. All solid media contained $1.5 \%(w / v)$ agar.

\footnotetext{
Abbreviations: OASS, $O$-acetylserine sulphydrylase; SP, sulphate permease: SF-medium, sulphur-free minimal medium.
} 
Table 1. E. coli strains and plasmids

Strain

$\mathrm{XPh} 43$

JA199

NK3

EC1184

EC 1185

EC2242

EC2243

EC2245

EC2246

EC2351

EC2352

EC2353

EC2356

EC2357

EC2358

EC2359

EC2360

Plasmid

$\begin{array}{ll}\text { pBC4042 } & \text { pBCO : : MudII4042 } \\ \text { pAMH1 } & \text { cys } M \\ \text { pAMH2 } & \text { cys } M \text { cysA } \\ \text { pASH8 } & \text { cys } M \text { cys } A \\ \text { pASH11 } & \text { cys } M \text { cys } A \\ \text { pASH13 } & \text { cys } M\end{array}$

Genotype/phenotype

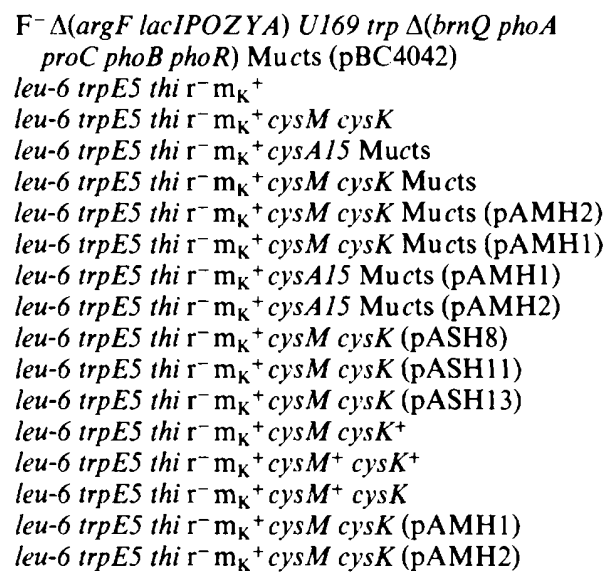

* Transductant from JA199 lysate $\times$ NK3 .

\author{
Reference \\ M. C. Casadaban, Univ. \\ of Chicago, USA \\ Stock collection \\ Hulanicka et al. (1986) \\ Stock collection \\ Mucts lysogen of NK3 \\ Transformant of EC 1185 \\ Transformant of EC1185 \\ Transformant of EC1184 \\ Transformant of EC1184 \\ Transformant of NK3 \\ Transformant of NK3 \\ Transformant of NK 3 \\ Transformant of NK3* \\ Transformant of NK 3 * \\ Transformant of NK 3 * \\ Transformant of NK3 \\ Transformant of NK3
}

Groisman et al. (1984).
This work
This work
This work
This work
This work

Enzyme assays. OASS activity was assayed as described by Kredich (1971). Sulphate permease (SP) activity was assayed according to Dreyfuss \& Pardee (1966). Protein was determined by the biuret method using bovine serum albumin as a standard.

In vivo cloning. This was done by use of mini-Mu containing a plasmid replicon, as described by Groisman $e t$ al. (1984). The essential feature of this method is thermal derepression of the mini-Mu-lac MudII4042 carried on the pUC9 derivative pBCO. MudII4042 contains, as well as Mucts and lac markers, a chloramphenicol resistance gene and the plasmid pACYC184 replicon. Strain EC1185, which is a Mucts lysogen of the double mutant NK3 (cys $K$ cys $M$ ), was used as recipient.

In vitro recombinant DNA techniques. Plasmid DNA isolated by the boiling method (Holmes \& Quigley, 1981) was purified in a $\mathrm{CsCl}$ gradient. Restriction endonuclease digestions and ligation reactions were carried out in buffers recommended by Maniatis et al. (1982). Transformation was performed according to Cohen et al. (1972). Transformants were selected either by antibiotic resistance on LB plates or by cysteine prototrophy on minimal plates.

Agarose gel electrophoresis. DNA fragments were separated in $1 \%(w / v)$ agarose gels in Tris/acetate buffer (40 mM-Tris, $20 \mathrm{~mm}$-sodium acetate, $1 \mathrm{~mm}$-EDTA, pH 8.2) and their lengths were estimated in comparison with standard DNA fragments.

\section{RESULTS}

Presence of two genes coding for OASS activity on the E. coli chromosome

In order to demonstrate the presence of two genes coding for OASS we transduced the cysteine auxotroph NK 3 (lacking OASS activity) to cysteine prototrophy using P1 phage grown on the wild-type strain. All transductants selected on minimal medium containing $\mathrm{SO}_{4}^{2-}$ as sulphur source were further characterized on the basis of their resistance to $10 \mathrm{mM}$-1,2,4-triazole and their ability to grow on $1 \mathrm{~mm}-\mathrm{S}_{2} \mathrm{O}_{3}^{2-}$ as sulphur source. Those discriminate between the genotypes as follows. OASS-A encoded by the cys $K$ gene catalyses the reaction between 1,2,4triazole and $O$-acetylserine producing 1,2,4-triazole-1-alanine, a compound not toxic for cells. However, the presence of this activity leads in parallel to exhaustion of the substrate for cysteine 
Table 2. OASS activities

Bacteria were grown on SF medium with $1 \mathrm{mM}-\mathrm{L}$-djenkolic acid or $0 \cdot 1 \mathrm{mM}$-L-cysteine. Results are means of three to five experiments; the deviations from these means were less then $10 \%$.

\begin{tabular}{|c|c|c|c|}
\hline \multirow[b]{3}{*}{ Strain } & \multirow[b]{3}{*}{ Relevant genotype } & \multicolumn{2}{|c|}{$\left[\mathrm{U}(\mathrm{mg} \text { protein })^{-1}\right]$} \\
\hline & & \multicolumn{2}{|c|}{ Sulphur source: } \\
\hline & & cysteine & djenkolic acid \\
\hline EC2356 & $\operatorname{cys} M \operatorname{cys} K^{+}$ & 0.52 & $7 \cdot 7$ \\
\hline EC2357 & $\operatorname{cys} M^{+} \operatorname{cys} K^{+}$ & 0.92 & $8 \cdot 0$ \\
\hline EC2358 & cys $M^{+} \operatorname{cys} K$ & $0 \cdot 18$ & 0.93 \\
\hline EC2243 & $\operatorname{cys} M \operatorname{cys} K(\mathrm{pAMH})$ & - & $0 \cdot 28$ \\
\hline EC2242 & $\operatorname{cys} M \operatorname{cys} K(\mathrm{pAMH} 2)$ & - & 0.46 \\
\hline EC2359 & $\operatorname{cys} M \operatorname{cys} K(\mathrm{pAMH})$ & $0 \cdot 15$ & $0 \cdot 33$ \\
\hline EC 2360 & $\operatorname{cys} M \operatorname{cys} K(\mathrm{pAMH} 2)$ & $0 \cdot 16$ & 0.40 \\
\hline EC2351 & cys $M$ cys $K$ (pASH8) & - & $0 \cdot 31$ \\
\hline EC2352 & $\operatorname{cys} M \operatorname{cys} K(\mathrm{pASH} 11)$ & -- & $0 \cdot 36$ \\
\hline EC2353 & $\operatorname{cys} M \operatorname{cys} K(\mathrm{pASH} 13)$ & - & $0 \cdot 49$ \\
\hline NK 3 & $\operatorname{cys} M \operatorname{cys} K$ & $0 \cdot 11$ & $0 \cdot 17$ \\
\hline EC1185 & $\operatorname{cys} M \operatorname{cys} K \mathrm{Mu} c \mathrm{ts}$ & $0 \cdot 12$ & $0 \cdot 10$ \\
\hline JA199 & Wild-type & 0.68 & $10 \cdot 6$ \\
\hline
\end{tabular}

synthesis and of an internal inducer of this regulon. Therefore, mutants impaired in the cysK gene are resistant to triazole ( $\mathrm{Trz}^{\mathrm{r}}$ ) (Hulanicka et al., 1974; Kredich et al., 1975). Nakamura et al. (1983) reported that in S. typhimurium thiosulphate is assimilated exclusively by OASS-B encoded by the $c y s M$ gene; $c y s M$ mutants are unable to grow on thiosulphate as sulphur source.

Three classes of $\mathrm{Cys}^{+}$transductants of the NK3 (cysM cysK) double mutant were found: (1) $c y s M^{+} c y s K$, (2) $c y s M c y s K^{+}$and (3) $c y s M^{+} c y s K^{+}$. OASS activity in representative transductants picked out of these three classes are summarized in Table 2. Transductants of class 2 and 3 are triazole-sensitive; they cannot be distinguished on the basis of the sulphydrylase activity assay. Mutations in the cysM gene do not lead to a measurable decrease of sulphydrylase activity in cys $K^{+}$strains. However, transductants of class 3 differ from transductants of class 2 by their ability to grow on thiosulphate as sulphur source. The observed OASS activity in $c y s M^{+} c y s K$ transductants was very low. However, their activity depended on the sulphur source in the medium (Table 2).

\section{Cloning with mini-Mu-lac containing a plasmid replicon}

Strain XPh43 lysogenic for Mucts and harbouring MudII4042 on plasmid pBCO was grown at $30^{\circ} \mathrm{C}$ and transferred to $42{ }^{\circ} \mathrm{C}$ to induce transposition-replication and lysis. The lysate obtained $\left(10^{9}\right.$ p.f.u. $\left.\mathrm{m}^{-1}\right)$ was used in transduction to cysteine prototrophy with the cys $M$ cys $K$ Mucts strain EC1184 as recipient. Chloramphenicol-resistant $\left(\mathrm{Cm}^{r}\right)$ transductants were obtained at a frequency of $10^{-5}$ p.f.u. Cysteine-independent $\left(\mathrm{Cys}^{+}\right)$transductants were found among $\mathrm{Cm}^{\mathrm{r}}$ colonies at a frequency of $1.5 \times 10^{-2}$.

Plasmid DNA was isolated from a few $\mathrm{Cys}^{+} \mathrm{Cm}^{r}$ transductants and used for transformation of strain EC1185 to cysteine prototrophy and $\mathrm{Cm}^{r}$. In this case all $\mathrm{Cm}^{r}$ colonies were Cys ${ }^{+}$and all $\mathrm{Cys}^{+}$colonies were $\mathrm{Cm}^{\mathrm{r}}$. These results indicated that both markers are carried on the same plasmid. Two transformants, EC2242 and EC2243, were chosen for further studies. Plasmid DNA from these strains was isolated and analysed on agarose gels. Strain EC2243 carries plasmid pAMHl containing a $3.0 \mathrm{~kb}$ fragment of the E. coli chromosome, and strain EC 2242 carries plasmid pAMH2 containing an $8.0 \mathrm{~kb}$ fragment of $E$. coli chromosome. Restriction mapping of the chromosomal fragments of these plasmids was made difficult due to the length of MudII4042 (Groisman et al., 1984). Therefore, in order to obtain more precise maps of these fragments they were recloned in pBR322. Plasmids complementing cysteine auxotrophy of the cys $M$ cys $K$ mutant NK 3 were selected. The construction of these plasmids is presented in Fig. 1. In pASH13 derived from pAMH1 the chromosomal insert is flanked by $1.0 \mathrm{~kb}$ (on the HindIII side) and $0.1 \mathrm{~kb}$ (on the Bam HI side) of mini-Mu-lac DNA. The chromosomal fragment of 

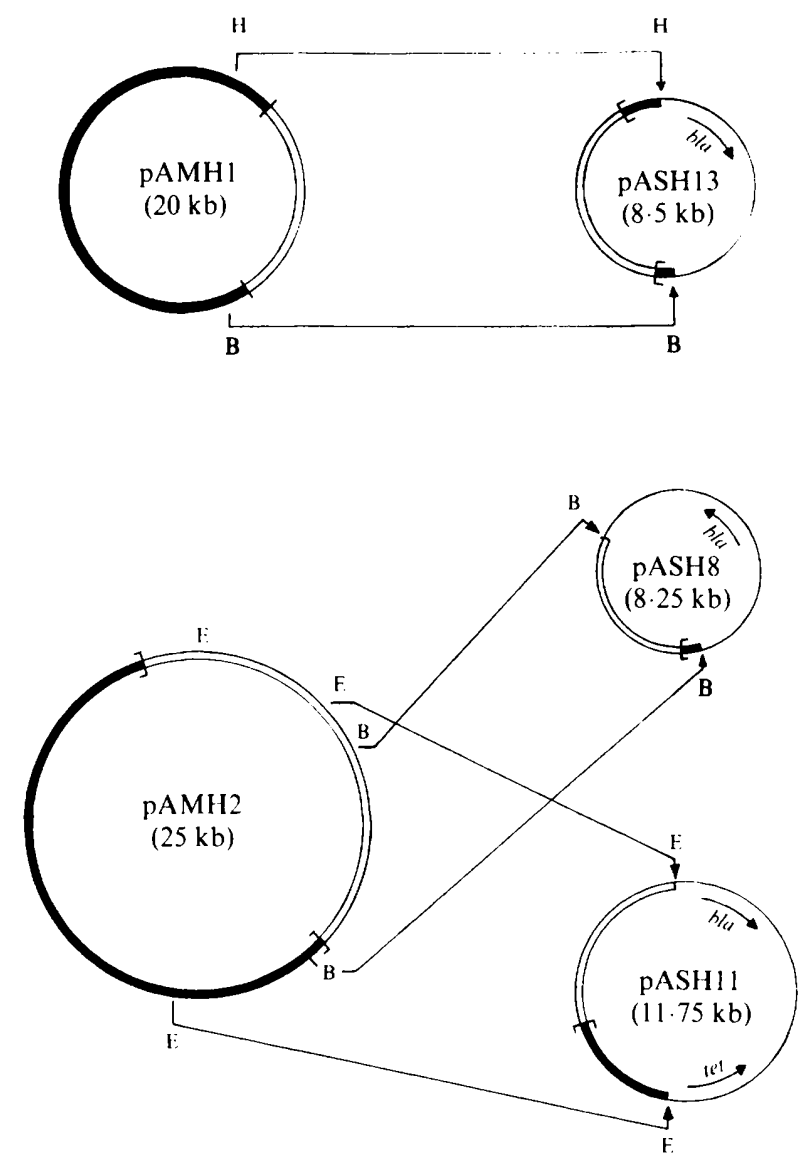

Fig. 1. Scheme of plasmid construction. Double lines represent fragments of $E$. coli chromosome, filled bars the vector MudII4042 and single lines the vector pBR322; bla, ampicillin resistance gene; tet. tetracycline resistance gene. Restriction enzymes: H, HindIII, E, EcoRI, B, BamHI.

pAMH2 was recloned either at the BamHI site (pASH8) or the EcoRI site (pASH11) of pBR322. Plasmids pASH8 and pASH11 contain $0.1 \mathrm{~kb}$ and $3.1 \mathrm{~kb}$ DNA of mini-Mu-lac vector, respectively. Digestion of the above plasmids with available restriction enzymes enabled us to establish the restriction maps of the cloned fragments (Fig. 2).

\section{OASS assay of transformants}

In order to check if the cysteine prototrophy of all transformants results from restoration of OASS activity, crude extracts of several transformants were assayed for OASS. The representative results shown in Table 2 demonstrate a slight increase in OASS activity by comparison with that observed in the cys $M$ cys $K$ mutant NK3. Nevertheless, the generation time of transformants was only slightly longer than that of the wild-type (100 and $90 \mathrm{~min}$ respectively, on minimal medium - data not shown). Since OASS-A activity constitutes the main fraction of sulphydrylase activity in the cell, a low level of OASS in transformants strongly suggests the presence of the cysM gene on the plasmids (Hulanicka et al., 1979).

Presence of the cys $A$ gene on $P A M H 2$ and its derivatives

In $S$. typhimurium the cys $A$ gene coding for SP is closely linked to the cys $M$ gene (Hulanicka $e t$ al., 1979). It was of interest to check if the constructed plasmids also carry the cys $A$ gene. The cysA mutant EC1184 was transformed to chloramphenicol or ampicillin resistance with the 


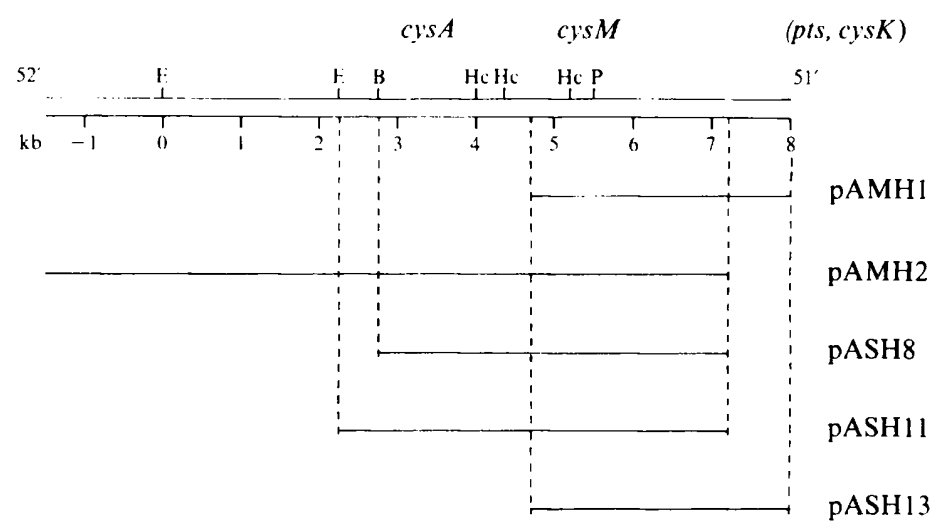

Fig. 2. Location of cys $A$ and $c y s M$ genes and restriction map of the studied fragments of the $E$. coli chromosome. Hc, HincII; B, BamHI; E, EcoRI; P, PstI. HincII and PstI were only mapped in the region between $2.2 \mathrm{~kb}$ and $8.0 \mathrm{~kb}$. No restriction sites for the following enzymes were found: $B g / \mathrm{II}$, $X$ hoI, HindIII and Sall. The restriction site for EcoRI (left-hand site) was arbitrarily designated zero.

\section{Table 3. SP activities}

Bacteria were grown on SF medium with 1 mM-L-djenkolic acid.

$\begin{array}{llc}\text { Strain } & \text { Relevant genotype } & \text { [nmol SO} \\ \text { EC2245 } & \text { cys } \mathrm{min}^{-1} \mathrm{ml}^{-1}\left(\mathrm{OD}_{650} \text { unit) }\right. & -1 \\ \text { EAM1) } & 0 \cdot 7 \\ \text { EC2246 } & \text { cysA (pAMH2) } & 5 \cdot 5 \\ \text { EC1184 } & \text { cysA } & 0 \cdot 0 \\ \text { JA199 } & \text { Wild-type } & 2 \cdot 7\end{array}$

constructed plasmids. Only pAMH 2 and its derivatives pASH 8 and pASH 11 complemented the cysteine auxotrophy of the cysA mutant. Results of the SP assay are presented in Table 3 . The level of SP activity in the transformant carrying pAMH2 is similar to that observed in the wildtype strain JA 199, the parental strain of the cysA mutant. In the transformant carrying pAMH1 the SP activity was low and similar to that found in the cys $A$ mutant.

Chromate inhibits the growth of Enterobacteriaceae. Strains impaired in cys $A$ are resistant to chromate because there is no uptake of the inhibitor. Therefore, we checked chromate resistance by measuring the growth inhibition zones caused by various chromate concentrations (data not shown). As expected, the cys $A$ mutant and the $c y s A / \mathrm{pAMH} 1$ transformant were resistant to chromate. The strain transformed with pAMH2 showed about 10 times higher sensitivity to the inhibitor than the wild-type strain JA199.

\section{DISCUSSION}

The final step of L-cysteine biosynthesis in $S$. typhimurium and $E$. coli consists of the sulphydrylation of $O$-acetylserine by free sulphide (K redich, 1971). Two enzymes, encoded by the cys $K$ and $c y s M$ genes, catalysing this reaction have been described in $S$. typhimurium (Hulanicka et al., 1979). These genes are cotransducible but separated by genes unrelated to sulphur metabolism (Hulanicka et al., 1986). Separation of the cysK gene from other cysteine genes of the cysteine regulon in this region was previously reported (Nelson et al., 1984).

In this paper we have studied whether in $E$. coli sulphydrylation of $O$-acetylserine is also catalysed by two separate enzymes, OASS-A and OASS-B, encoded by the genes $c y s K$ and $c y s M$, respectively.

Cysteine prototrophy of cys $K$ mutants of $E$. coli suggested the existence of a second OASS enzyme in $E$. coli (Wiater \& Hulanicka, 1979). The results presented in this paper, i.e. the 
presence of three classes of $\mathrm{Cys}^{+}$transductants of the NK 3 strain (which completely lacks OASS activity) and the complementation of the cysteine auxotrophy of the NK3 strain by the constructed plasmids clearly indicate that indeed a cys $M$ gene, coding for the second OASS enzyme, exists in $E$. coli.

In $S$. typhimurium the product of the $c y s M$ gene, OASS-B, enables utilization of thiosulphate as a sulphur source. The finding that the intact cys $M$ gene is required for growth on thiosulphate as a sulphur source indicates that OASS-B of $E$. coli also displays the second activity. It catalyses the reaction between $O$-acetylserine and thiosulphate to give $S$-sulphocysteine.

In $S$. typhimurium the cys $M$ gene is situated close to the cys $A$ gene and the pts operon (Nelson et al., 1984; Hulanicka et al., 1986). The cysA20 deletion covers cysM (Hulanicka et al., 1979). The close linkage of the $c y s A$ gene with the pts operon in $E$. coli was previously established by PI transduction (Karbonowska et al., 1977). Therefore, it was of interest to check if constructed plasmids also carry the cys $A$ gene. Complementation by pAMH2 of $c y s A$ mutant EC1184, sulphate permease assay (Table 3 ) and chromate resistance tests indicate that the chromosomal fragment of pAMH2 carries the $c y s A$ gene.

The restriction maps of cloned fragments and their comparison with the map of this region reported by Boronat et al. (1983) allowed location of the cys $M$ gene between cys $A$ and the pts operon (Fig. 2).

Assay of OASS activities in crude extracts of $c y s M^{+} c y s K$ transductants of NK 3 strain and its transformants carrying plasmids with the cys $M$ gene showed a low increase of enzyme activity in comparison with the level found in the NK3 mutant. However, even such a low increase of enzyme activity was sufficient to restore cysteine prototrophy.

The level of cysteine enzymes in the wild-type cells depends on the sulphur source in the medium (Kredich, 1971). L-Cysteine causes repression whereas growth on a poor sulphur source such as L-djenkolate leads to a derepressed level of cysteine enzymes. Results presented in Table 2 show that growth of the transductant $c y s M^{+} c y s K$ on L-djenkolate gives an OASS-B level higher than that found in L-cysteine-grown cells. The dependence of OASS-B activity on the sulphur source indicates that the expression of the cys $M$ gene is regulated by the same factors that control other enzyme activities of the cysteine regulon.

A similar regulation of OASS activities was found in transformants carrying plasmids with a cloned cy's $M$ gene. This finding indicates that the expression of the cys $M$ gene proceeds from its own promoter. Interestingly, the presence of the $c y s M$ gene on a high copy number plasmid did not lead to an increase of OASS activity. Similar observations were made with plasmids carrying other cysteine genes (unpublished results). Plasmid pGBK5 carrying the cysJIH operon of $S$. typhimurium on pBR322 did not cause a higher level of sulphate reductase in crude extracts of transformants, probably because of limitation of the positive regulatory protein, the $c y s B$ gene product.

This work was supported by the Polish Academy of Sciences within the project 3.13.

\section{REFERENCES}

Boronat, A., Britton, P., Jones-Mortimer, M. C., KornberG, H. L., Lec, L. G., Murfitt, D. \& PARRA, F. (1984). Location on the Escherichia coli genome of a gene specifying $O$-acetylserine (thiol)lyase. Journal of General Microbiology 130, 673-685.

Britton, P., Murfitt, D., Parra, F., Jones-Mortimer, M. C. \& Kornberg, H. L. (1982). Phosphotransferase-mediated regulation of carbohydrate utilization in Escherichia coli K 12: identification of the products of genes on the specialized transducing phages iex (crr) and gsr (tgs). EMBO Journal 1, 907911.

Britton, P., Boronat, A., Hartley, D. A., JonesMortimer, M. C., Kornberg, H. L. \& Parra, F. (1983). Phosphotransferase-mediated regulation of carbohydrate utilization in $E$. coli $\mathrm{K} 12$ : location of the gsr (tgs) and iex (crr) genes by specialized transduction. Journal of General Microbiology 129. 349-356.

Bukhari, A. J. \& LJungquist, E. (1977). In DNA Insertion Elements, Plasmids and Episomes. Edited by A. J. Bukhari, J. A. Shapiro \& S. L. Adhya. Cold Spring Harbor, NY: Cold Spring Harbor Laboratory.

Cohen, S. N., Chang, A. C. Y. \& Hsu, L. (1972). Nonchromosomal antibiotic resistance in bacteria: genetic transformation of Escherichia coli by R-factor DNA. Proceedings of the National Academy of Sciences of the United States of America 69, 21102114. 
Dreyfuss, J. \& Pardee, A. B. (1966). Regulation of sulphate transport in $S$. typhimurium. Journal of Bacteriology 91, 2275 2280 .

Fimmel, A. L. \& Loughin, R. E. (1977). Isolation and characterization of cysK mutants of Escherichia coli K12. Journal of General Microhiology 103, 37-43.

Groisman, E. A., Castillho, B. A. \& Casadaban, M. J. (1984). In vivo DNA cloning and adjacent gene fusing with a mini-Mu-lac bacteriophage containing a plasmid replicon. Proceedings of the National Academy of Sciences of the United States of America 81, 1480-1483.

Holmes, D. S. \& Quigley, M. (1981). Rapid boiling method for the preparation of bacterial plasmids. Analytical Biochemistry 114, 193-197.

Hulanicka, M. D., Klopotowski, T. \& Smith, D. A. (1972). The effect of triazole on cysteine biosynthesis in Salmonella typhimurium. Journal of General Microbiology 72, 291-301.

Hulanicka, M. D., Kredich, N. M. \& Treiman, D. M. (1974). The structural gene for $O$-acetylserine sulphydrylase A in Salmonella typhimurium. Journal of Biological Chemistry 249, 867-872.

Hulanicka, M. D., Halloquist, S. G., Kredich, N. M. \& Mojica, A. T. (1979). Regulation of $O-$ acetylserine sulphydrylase B by L-cysteine in Salmonella typhimurium. Journal of Bacteriology' 140, 141146.

Hulanicka, M. D.. Garret, Ch., Jagura-Burdzy, G. \& Kredich, N. M. (1986). Cloning and characterization of the cys $A M K$ region of Salmonella typhimurium. Journal of Bacteriology 168, 322 327.
Karbonowska, H., Wiater, A. \& Hulanicka, M. D. (1977). Sulphate permease of Escherichia coli K 12. Acta biochimica polonica 24, 329-334.

KREDICH, N. M. (1971). Regulation of L-cysteine biosynthesis in Salmonella typhimurium. Journal of Biological Chemistry 246, 3474-3484.

Kredich, N. M., Foote, L. J. \& Hulanicka, M. D. (1975). Studies of the mechanism of inhibition of Salmonella typhimurium by 1,2,4-triazole. Journal of Biological Chemistry 250, 7324-7331.

Luria, S. E. \& Burrows, J. W. (1957). Hybridization between Escherichia coli and Shigella. Journal of Bacteriology 74, 461-476.

Maniatis, T., Fritsch, E. F. \& Sambrook, J. (1982). Molecular Cloning. A Laboratory Manual. Cold Spring Harbor, NY: Cold Spring Harbor Laboratory.

Miller, J. H. (1972). Experiments in Molecular Genetics. Cold Spring Harbor, NY: Cold Spring Harbor Laboratory.

Nakamura, T., Kon, Y., Iwashi, H. \& Equihi, Y. (1983). Evidence that thiosulphate assimilation by Salmonella typhimurium is catalysed by cysteine synthase B. Journal of Bacteriology 156, 656-662.

Nelson, S. O., Schuitema, A. R. J., Benne, R., van der Ploeg, L. H. T., Plijter, J. S., Aan, F. \& Postma, P. W. (1984). Molecular cloning, sequencing and expression of the crr gene: the structural gene for IIIGle of the bacterial PEP:glucose phosphotransferase system. EMBO Journal 3, 1587-1593.

Wiater, A. \& Hulanicka, D. (1979). Properties of cys $K$ mutants of Escherichia coli $\mathrm{K} 12$. Acta biochimica polonica 26, 21-28. 